\title{
Oito Poemas de 杜甫 Du Fu
}

António Graça de Abreu

Du Fu (712-770) é com 李白Li Bai, ou Li Po (701-762), o maior poeta dos trinta séculos de poesia chinesa.

Infelizmente quase desconhecido em Portugal, viveu em plena dinastia 唐 Tang (618-907) em tempos de apogeu do grande império subitamente quebrado por uma cruenta guerra civil - a rebelião do general An Lushan que entre 755 e 763 provocou doze milhões de mortos quando o total da população chinesa rondava então os cinquenta e seis milhões de pessoas - que deixou um país exangue, devastado pela fome e pela guerra.

Toda a vida e também a poesia de $\mathrm{Du}$ Fu (leia-se Tu Fu) está marcada, de início, pelos anos de despreocupação face ao dia a dia, uma existência pautada pela alegre vagabundagem de terra em terra, mas logo depois chegaram tempos difíceis, o poeta não conseguiu passar os exames imperiais e, na boa tradição da sua família, ascender a mandarim. Ganhava umas míseras sapecas ao serviço de poderosos, e mais tarde a pobreza era o seu quotidiano como insignificante funcionário da corte em Xi'an. Depois sobrevieram as doenças, a guerra, a fuga aos conflitos bélicos, de província em província, sempre na companhia da abnegada esposa e dos cinco filhos pequenos. Um deles haveria de morrer de fome e disso nos dá $\mathrm{Du} \mathrm{Fu}$ doloroso testemunho num dos seus mais pungentes poemas.

Os chineses consideram-no o "santo dos poetas" e costumam dizer que os poemas de Du Fu são História em poesia. Todos os graves acontecimentos da época em que viveu aparecem genialmente retratados em muitas das estrofes que escreveu. Por isso conhecemos tão bem a China dessa época e a vida do poeta. $\mathrm{Na}$ poesia de $\mathrm{Du} \mathrm{Fu}$ surge também o gosto pelos simples prazeres de existir, a amizade entre letrados, a passagem por vilas e cidades, as descrições da majestosa natureza por onde o poeta se dilui fazendo parte de um todo, montanhas e rios, nuvens, chuva e céu azul. 
Du Fu deixou-nos 1.400 poemas, um dos maiores tesouros da poesia chinesa, e continua, há muitos séculos a ser lido e estudado por centenas de milhões de chineses. O seu legado faz parte da herança cultural dos povos do mundo

Morreu aos 58 anos, na miséria, na companhia da família na barca onde descia o rio Xiang, na província de Hunan.

Traduzir Du Fu é tarefa impossível. Mas porque é impossível, as traduções acontecem. O poeta chinês burilava de tal modo o correr dos versos, a construção do poema é tão complexa, com permanentes jogos de palavras, alusões literárias, rimas internas e ritmos surpreendentes que muitos dos maiores tradutores para língua inglesa e francesa não têm tido coragem para se aventurar na engenhosa tarefa de o traduzir. Que Du Fu me perdoe a ousadia de tentar verter alguma da sua poesia para a língua de Camões e Pessoa.

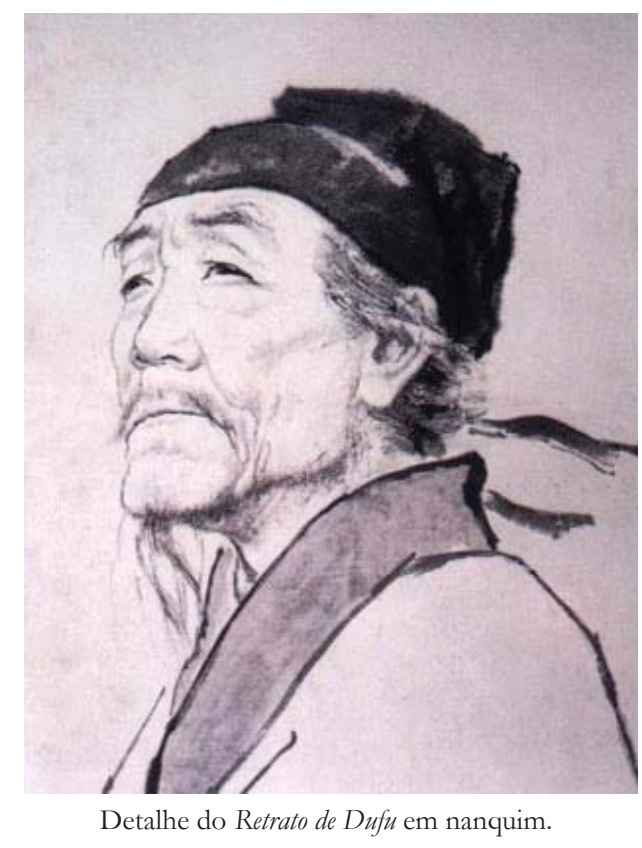

Fonte: http://baike.baidu.com/view/2211.htm 


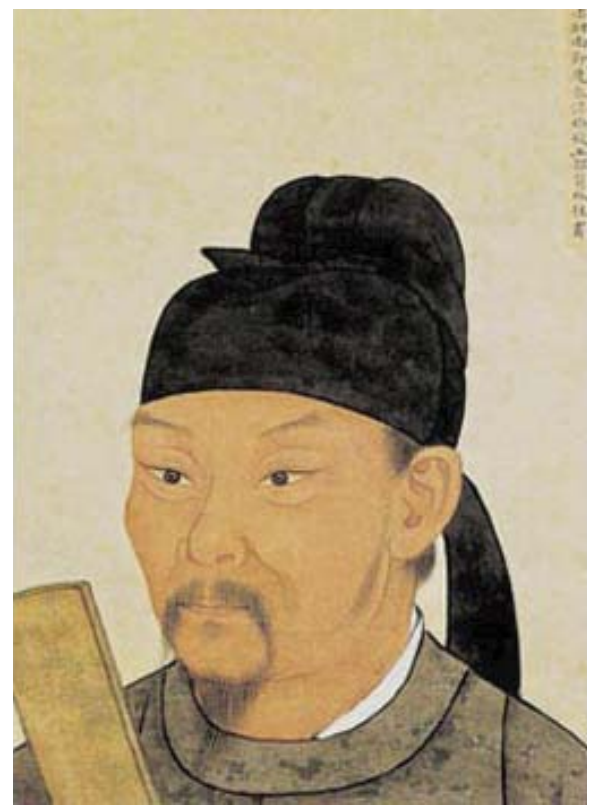

Retrato em nanquim de Du Fu

Fonte: http://baike.baidu.com/view/2211.htm

\section{Ao entardecer}

Raios de sol oblíquos cintilam nas cortinas de pérola, flores da Primavera brilham na margem do rio, perfumes entorpecentes sobem do jardim, pardais chilreantes acolhem-se entre a ramaria, nos barcos parados acendem-se fogões para a refeição da noite, uma nuvem de insectos invade o meu pátio.

Quem inventou este vinho turvo?

Basta uma taça para dissipar dez mil tristezas.

落日在帘钩, 溪边春事幽。 芳菲缘岸戋, 樵䁷倚滩舟。 啅雀争枝坠, 飞虫满院游。 浊醪谁造汝, 一酌散千忧。 


\section{Os cavalos bárbaros do mandarim Fang}

Famosos os cavalos bárbaros de Ferghana,

talhados a cinzel, esbeltos, garbosos.

Orelhas espetadas como pontas de bambu,

quatro patas ligeiras para cavalgar o vento.

Nada os detém, por todos os caminhos,

podemos confiar-lhes a vida e a morte.

Nobres corcéis, dividimos os sonhos,

por mil léguas, abertos à vastidão do mundo.

\section{房兵曹胡马}

胡马大宛名, 锋棱瘦骨成。

竹批双耳峻, 凤入四蹄轻。

所向无空阔, 真堪托死生。

骁腾有如此, 万里可横行。 


\section{A beldade abandonada}

Filha de família ilustre e poderosa que o tempo reduziu a erva e pó, vive hoje esquecida num vale solitário e não havia mulher mais bonita do que ela! Mortos os irmãos nas rebeliões do império, cargos, honrarias não lhes salvaram a vida, ninguém encontrou seus corpos.

O mundo não se ocupa de quem passa, a fortuna é chama de uma vela ao vento. Seu marido, o coração em viagem, procurou nova mulher, bela como jade. As flores sabem quando desce a noite, quando os patos-mandarins nadam lado a lado. Ele só vê o sorriso da jovem concubina, não ouve o pranto da antiga esposa. Puras as águas dos regatos na montanha, lamacentas, sujas ao chegar à planície.

Ela mandou a criada vender algumas pérolas, comprou comida, colmo para cobrir o telhado. Agora colhe flores, não para enfeitar os cabelos, nos dedos, já se soltam os anéis.

Esquecendo o ar gélido nas mangas de seda, encosta-se aos bambus e olha o pôr-do-sol.

绝代有佳人, 幽居在空谷。 自云良家女, 零落依草木。 关中昔丧乱, 兄弟遭杀翏。 官高何足论, 不得收骨肉。 世情恶衰歇, 万事随转烛。 夫婿轻薄儿, 新人美如玉。 合昏尚知时, 驾莺不独宿。 但见新人笑, 那闻旧人哭。 在山泉水清, 出山泉水浊。 侍婢卖珠回, 牵萝补茅屋。 摘花不插发, 采柏动盈掬。 天寒翠袖薄, 日暮倚修竹。 


\section{O recrutador de Shihao}

Cheguei esta noite à aldeia de Shihao, veio também um oficial para alistar soldados. Um homem, já idoso, saltou um muro e fugiu mas a esposa teve de falar com o militar que gritava, colérico, enquanto a mulher chorava. "Tenho três filhos soldados na guarnição de Yue, acabei de receber carta de um deles e a notícia da morte dos outros dois no campo de batalha. Os mortos estão para sempre mortos, sentimos vergonha por continuar vivos. Agora, resta apenas o meu neto, um bebé mamando numa pobre mãe coberta de farrapos. $\mathrm{Eu}$, velha, sem forças, posso partir convosco, se necessário esta noite mesmo, poderei servir em Heyang, cozinharei para as tropas." Perderam-se as palavras na escuridão da noite, ouviram-se, de quando em quando, soluços confusos. Ao amanhecer, ao retomar a jornada, apenas o velho se despediu de mim.

\section{石壕吏}

暮投石壕村, 有吏夜捉人。 老翁逾墙走, 老妇出门看。 吏呼一何怒! 妇啼一何苦! 听妇前致词：“三男业城戍。 一男附书至, 二男新战死。 存者且偷生, 死者长已矣! 室中更无人, 惟有乳下孙。 有孙母未去, 出入无完裙。 老妪力虽衰, 请从吏夜归。 急应河阳役, 犹得备晨炊。” 夜久语声绝, 如闻泣幽咽。 天明登前途, 独与老翁别。 


\section{Balada das carroças da guerra}

Como chiam as carroças, como relincham os cavalos!

Marcham os soldados, arcos e flechas à cintura,

pais, mães, esposas, filhos correm para um adeus,

batem com os pés, rasgam a roupa, barram a estrada, choram,

a poeira não deixa ver a ponte de Xiangyang,

o pranto eleva-se, sobe até às nuvens.

Alguém passa e questiona os soldados:

"Somos recrutados à força,

aos quinze anos guardamos as margens do rio Amarelo, a norte,

aos quarenta, continuamos nos campos de batalha, a oeste."

Ao partir, os chefes de aldeia colocam-lhes turbantes,

ao regressar, cruzam a fronteira, os cabelos brancos.

Nos campos distantes, o sangue corre como água do mar,

a ambição imperial não tem limites.

Não vêem duzentas vilas a leste das montanhas,

mil aldeias, dez mil lugarejos

onde só crescem silvas e espinheiros?

Mulheres possantes pegam nos arados, lavram a terra,

os cereais crescem, quem os vai colher?

Os soldados de Qin resistem em combates terríveis

levados para a guerra como cães ou galinhas.

Um venerável ancião faz perguntas,

os combatentes não ousam lamentar-se,

mesmo no Inverno, os soldados não param no desfiladeiro.

Os mandarins locais exigem mais impostos,

como é possível pagar ainda mais impostos?

Pouca sorte ao nascer hoje um rapaz,

e que sorte ao nascer uma menina!

A menina pode casar com um vizinho,

o rapaz é para enterrar sob montões de erva.

Não vêem nas paragens distantes de Qingha

tantos ossos brancos que ninguém recolheu?

Quanta injustiça!

Gemem fantasmas novos, choram velhos,

Um céu cinzento, a chuva encharcando tudo,

quantos gritos e gemidos!... 
兵车行

车辚辚, 马萧萧, 行人弓箭各在腰。 耶娘妻子走相送, 尘埃不见咸阳桥。 牵衣顿足拦道哭, 哭声直上干云霄! 道旁过者问行人, 行人但云点行频。 或从十五北防河, 便至四十西营田。 去时里正与裹头, 归来头白还戍边! 边亭流血成海水, 武皇开边意未已。 君不闻, 汉家山东二百州, 千村万落生荆杞! 纵有健妇把锄犁, 禾生陇亩无东西。 况复秦兵耐苦战, 被驱不异犬与鸡。 长者虽有问, 役夫敢申恨? 且如今年冬, 未休关西卒。 县官急索租, 租税从何出? 信知生男恶, 反是生女好。 生女犹得嫁比邻, 生男埋没随百草! 君不见, 青海头, 古来白骨无人收。 新鬼烦冤旧鬼哭, 天阴雨湿声啾啾! 


\title{
Em casa do amigo Zheng Zi, letrado do reino de Wei
}

Felizes esta noite à luz da mesma candeia,

envelhecemos, passaram céleres os anos de juventude, os amigos, quase todos, partiram para os jardins da escuridão.

Emocionado, sentes o bater do meu coração.

Vinte anos depois, eis-me sentado no teu lar,

eras ainda solteiro no nosso último encontro,

hoje acaricio teus filhos e filhas, tão bem educados,

debruçaste-te sobre eles como outrora

te inclinavas sobres os teus grandes poemas.

Perto de tua casa, a saudação do teu filho mais velho,

quis saber da minha saúde, a família, a terra natal.

Desculpa, rapaz, não te ter respondido,

na altura, eu ouvia o murmúrio das águas no regato

que me conhecem

desde quando eu era pequeno como tu.

A nossa velha amizade, meu caro Zheng,

é um bem, um precioso tesouro,

chegámos à idade em que o tempo do passado

tem mais perfume que ramos de lilases em flor.

\section{赠卫八处士}

\begin{abstract}
人生不相见, 动如参与商。
今夕复何夕, 共此灯烛光。 少壮能几时, 䯶发各已苍。

访旧半为鬼, 惊呼热中肠。

焉知二十载, 重上君子堂。

昔别君未婚, 儿女忽成行。

怡然敬父执, 问我来何方。

问答乃未已, 驱儿罗酒浆。

夜雨剪春韭, 新炊间黄梁。

主称会面难, 一举累十解。

十角赫不醉, 感子故意长。

明日隔山岳, 世事两茫茫。
\end{abstract}


Bêbado, uma canção

Muitos ascenderam ao topo da hierarquia, tu, meu amigo, continuas a padecer ao frio. Nas grandes mansões, empanturrados com iguarias, tu, meu amigo, mal consegues uma malga de arroz. A tua filosofia, um coração cristalino, pouca ambição, o teu talento, superior ao dos letrados do passado. Respeitado pela tua virtude, condenado, sem glória, a deixar o teu nome para além dos séculos. És um rústico que não é desta terra, de cabelos finos, motivo de mofa e zombaria. Queres arroz, vais ao celeiro imperial, obténs ainda cinco colheres por dia, mas se queres abrir o coração, vem ter comigo, meu amigo. Quando ganho umas tantas moedas, cuido de ti, vamos gastá-las em vinho. Que nos interessa a pompa, o luxo, as cortesias, somos gente simples, descuidada e livre!...

Meu mestre, enchemos, bebemos as taças até ao fim, em silêncio na noite da Primavera.

Lá fora, a chuva fina como flores caindo dos telhados, apagando as lanternas. Entoamos cânticos, animados, iluminados por espíritos a montante, a jusante do rio. Para quê pensar tanto no destino? Sim, a fome, e por túmulo, uma vala qualquer. Outrora, um grande poeta lavava canecas de vinho, um ilustre letrado lançou-se de uma torre.

Quem somos nós, no fim de tudo? Melhor retirarmo-nos cedo, voltar a lavrar a terra, cuidar dos telhados de colmo, dos caminhos, do musgo. Os ensinamentos de Confúcio, afinal para que servem? Sábio, salteador de estradas, todos regressam ao pó. Para quê tanta tristeza, tanto queixume?

Estamos vivos, vamos beber umas taças de vinho. 
醉时歌

诸公亵袠登台省, 广文先生官独冷。 甲第纷纷厌粱肉, 广文先生饭不足。 先生有道出羲皇, 先生有才过屈宋。 德尊一代常轗轫, 名垂万古知何用。 杜陵野客人更虽, 被褐短窄髸如丝。 日冞太仓五升米, 时赴郑老同襟期。 得钱即相受, 活酒不复疑。 忘形到尔汝, 痛饮真吾师。

清夜沈沈动春酌, 灯前细雨檐花落。 但觉高歌有鬼神, 焉知饿死填沟壑。 相如逸才亲涤器, 子云识字终投阁。 先生早赋归去来, 石田茅屋荒苍苔。 儒术于我何有哉, 孔丘盗跖俱尘埃。 不须闻此意惨怆, 生前相遇且衔杯。

Pensamentos de uma noite em viagem

Nas ervas da margem, a carícia suave da brisa,

a barca solitária, o mastro alto na noite, caem estrelas na vastidão da terra, nasce a lua, corre o Grande Rio. Serei um dia famoso entre os poetas? Velho e doente, o mandarim afasta-se, vogando ao sabor do vento, simples gaivota entre céu e terra.

旅夜书怀

细草微风岸, 危樯独夜舟。

星垂平野阔, 月涌大江流。

名岂文章著? 官应老病休。

飘飘何所似, 天地一沙鸥。 